\title{
ANTIBIOTIC SENSITIVITY OF ACUTE RESPIRATORY INFECTION PATIENTS IN BHAYANGKARA HOSPITAL BENGKULU
}

\author{
Zamharira Muslim, Regita Pratiwi Mahardika, Putri Widelia Welkriana \\ Poltekkes Kemenkes Bengkulu \\ Jalan Indragiri Nomor 03 Padang Harapan Kota Bengkulu, 38225 \\ e-mail: zamhariramuslim@yahoo.com
}

Submitted: $15^{\text {th }}$ March 2020; Accepted: $12^{\text {th }}$ May 2020

https://doi.org/10.36525/sanitas.2020.3

\begin{abstract}
The high incidence of antibiotic resistance in the treatment of infections today is very worrying. The main therapy in patients with acute respiratory infections (ARI) is using antibiotics. This study aims to determine the sensitivity of several antibiotics to the bacteria that cause ARI. The design of this study is quasi-experimental. This sensitivity testing uses the disc diffusion method (Kirby Bauer). The antibiotics used are ampicillin and cefotaxime. The results obtained are that the antibiotic ampicillin resistant by $86.26 \%$ and $13.63 \%$ are still sensitive to the bacteria that causes ARI. The same thing also happened to cefotaxime antibiotics, most of which were resistant $(59.09 \%)$, intermediate $(9.09 \%)$, and most were still sensitive $(31.81 \%)$ to bacteria that infect the respiratory tract. From the results obtained it can be concluded that the incidence of bacterial resistance to ampicillin and cefotaxime is very high against bacteria that cause ARI.
\end{abstract}

Keywords: antibiotic sensitivity, acute respiratory infection, ampicillin, cefotaxim

This is an open access journal, and articles are distributed under the terms of the Creative Commons Attribution-Non Commercial-Share Alike 4.0 License, which allows others to remix, tweak, and build upon the work non-commercially, as long as appropriate credit is given and the new creations are licensed under the identical terms.

C)2020 Sanitas 


\title{
SENSITIVITAS ANTIBIOTIK TERHADAP PASIEN INFEKSI SALURAN PERNAPASAN AKUT DI RUMAH SAKIT BHAYANGKARA KOTA BENGKULU
}

\begin{abstract}
ABSTRAK
Tingginya kejadian resistensi antibiotik dalam pengobatan infeksi saat ini sangat mengkhawatirkan. Terapi utama pada pasien Infeksi Saluran Pernapasan Akut (ISPA) adalah menggunakan antibiotik. Penelitian ini bertujuan untuk mengetahui sensitivitas beberapa antibiotik terhadap bakteri penyebab ISPA. Desain penelitian ini adalah quasi eksperimen. Pengujian sensitivitas ini menggunakan metode disc diffusion (Kirby Bauer). Antibiotik yang digunakan yaitu ampisilin dan sefotaksim. Hasil yang didapat yaitu bahwa antibiotik ampisilin resisten sebesar $86,26 \%$ dan $13,63 \%$ masih sensitif terhadap bakteri penyebab ISPA. Hal yang sama juga terjadi pada antibiotik Sefotaksim sebagian besar terjadi resisten $(59,09 \%)$, intermedien $(9,09 \%)$, dan hampir sebagian masih sensitif $(31,81 \%)$ terhadap bakteri yang menginfeksi saluran pernapasan. Dari hasil yang didapat dapat disimpulkan bahwa kejadian resistennya bakteri terhadap ampisilin dan sefotaksim sangat tinggi terhadap bakteri penyebab ISPA.
\end{abstract}

Kata kunci : sensitivitas antibiotik, Infeksi Saluran Pernapasan Akut, ampisilin, sefotaksim

\section{PENDAHULUAN}

Infeksi pernafasan merupakan penyebab utama kematian pada bayi negara berkembang. Meskipun Global Burden of Disease Study 2020 mengungkapkan lebih sedikit kematian terkait dengan infeksi saluran pernapasan yang lebih rendah daripada 2 dekade lalu, terlalu banyak yang masih sekarat (1). Infeksi saluran napas atas (ISPA) meliputi rhinitis, sinusitis, faringitis, laringitis, epiglotitis, tonsilitis, otitis (2). Berdasarkan data dari Dinas Kota Bengkulu menunjukkan prevalensi pada tahun 2017 insiden Infeksi Saluran Pernapasan Akut (ISPA) diperkirakan terdapat 23.263 kasus.

Antibiotik mampu membunuh atau menghambat pertumbuhan bakteri. Penggunaan antibiotik sebagai terapi dalam mengobati infeksi harus tepat, aman dan rasional. Penggunaan antibiotik rasional jika memenuhi kriteria yang sesuai dengan indikasi penyakit, dosis yang diberikan tepat dan memenuhi kebutuhan individu, cara pemberian dilakukan dengan jangka waktu yang memadai dan biaya yang terjangkau (3). Efek yang terjadi bila penggunaan antibiotik tidak rasional adalah resistensi bakteri terhadap antibiotik (4). Antibiotik yang efektif dan aman telah berkembang begitu pesat sehingga dapat mengurangi mortalitas akibat penyakit infeksi secara drastis. Namun keberhasilan tersebut terganggu dengan banyaknya bakteri yang resisten terhadap antibiotik. Konsekuensi yang tidak terhindarkan 
akibat meluasnya penggunaan senyawa antibiotika adalah timbulnya patogen yang resisten antibiotika, dan peningkatan efek samping (5).

Antibiotik yang masih sering digunakan untuk terapi pengobatan penyakit ISPA yaitu amoksisilin dan sefotaksim (6). Penggunaan amoksisilin telah lebih dari 20 tahun, dan terus menjadi salah satu antibiotik yang paling banyak digunakan yang tersedia untuk penggunaan klinis, terutama dalam pengobatan infeksi saluran pernapasan. Amoksisilin dan asam klavulanat sekarang paling umum digunakan dalam pengobatan empiris infeksi saluran pernapasan bakteri, seperti communityacquired pneumonia (CAP), acute exacerbations of chronic bronchitis (AECB), acute bacterial rhinosinusitis (ABS) dan acute otitis media (AOM) (7). Sefotaksim telah berhasil digunakan pada pasien yang gagal merespon antibiotik lain, dan pada infeksi yang disebabkan oleh organisme yang kebal terhadap terapi biasa, seperti Enterobacteriaceae yang kebal terhadap sefalosporin lain, gentamisin dan/atau karbenisilin Serratia marcescens dan Klebsiella pneumoniae resisten terhadap semua antibiotik yang tersedia secara komersial; Haemophilus influenzae yang kebal terhadap ampisilin; dan Neisseria gonorrhoeae yang resisten terhadap penisilin (8). Penelitian ini bertujuan untuk melihat tingkat sensitifitas ampisilin dan sefotaksim terhadap bakteri penyebab ISPA.

\section{METODE PENELITIAN}

Penelitian ini dilakukan menggunakan metode desain deskriptif dengan pendekatan cross sectional. Pengambilan sampling dilakukan dengan accidental sampling. Sampel yang digunakan dalam penelitian ini adalah sputum. Kriteria sampel pada penelitian ini adalah sputum pasien rawat jalan yang didiagnosa ISPA di RS Bayangkara Kota Bengkulu dari bulan April hingga Juli 2019. Jumlah sampel yang didapatkan berjumlah 22 pasien. Pemeriksaan sampel dilakukan di Laboratorium Terpadu Poltekkes Kemenkes Bengkulu.

\section{Alat}

Alat yang digunakan adalah sebagai berikut: petridisk steril (pyrex $\left.{ }^{\circledR}\right)$, labu ukur $\left(\right.$ pyrex $\left.^{\circledR}\right)$, kaca arloji $\left(\right.$ pyrex $\left.{ }^{\circledR}\right)$, pinset $\left(\right.$ goot ts $\left.-14^{\circledR}\right)$, beaker glass, corong (pyrex $\left.{ }^{\circledR}\right)$, erlenmeyer $\left(\right.$ pyrex $\left.{ }^{\circledR}\right)$, pipet ukur $\left(\right.$ pyrex $\left.{ }^{\circledR}\right)$, oven (memmert un5 $\left.5^{\circledR}\right)$, pipet tetes (oneme $^{\circledR}$ ), autoklaf (all american type $\left.75 x^{\circledR}\right)$, gelas ukur (pyrex ${ }^{\circledR}$ ), mikropipet dragon 
med, spatula stainless steel, tabung reaksi (pyrex ${ }^{\circledR}$ ), penggaris stainless steel, ose disposable $\left(\right.$ isolab $\left.^{\circledR}\right)$, kertas saring whatman, etiket, incubator (memmert ICO105med $\left.^{\circledR}\right)$, bunsen, kapas lidi steril, hotplate $\left(\right.$ kenko $\left.^{\circledR}\right)$.

\section{Bahan}

Bahan yang digunakan pada penelitian ini adalah media $\mathrm{Na}\left(\right.$ Himedia $\left.^{\circledR}\right)+$ darah, pewarnaan gram, sputum, aquades steril (waterone), media Mueller Hinton Agar atau MHA $\left(\right.$ oxoid $\left.^{\circledR}\right)$, Nacl Steril $\left(\right.$ widatra $\left.^{\circledR}\right)$, cakram disk antibiotik ampisilin dan sefotaksim $\left(\right.$ oxoid $\left.^{\circledR}\right)$.

\section{Pengambilan Sampel}

Sebelum pengambilan sampel terlebih dahulu diminta kesediaan pasien untuk menjadi responden dalam penelitian ini menggunakan Inform Concern. Cara pengambilan sampel sputum yaitu sputum yang dikeluarkan setelah pasien kumurkumur dan dengan sekali batuk. Sputum dimasukkan ke dalam pot sputum steril yang telah disediakan lalu tutup rapat dan diberi label identitas pasien.

\section{Penanaman dan Pembiakan}

Sampel sputum dari wadah diambil 1 ose steril, kemudian diusapkan ke dalam media Blood Agar Plate (BAP). Media tersebut diinkubasi pada suhu $37^{\circ} \mathrm{C}$ selama 24 jam.

\section{Melakukan Pewarnaan Gram}

Setelah dilakukan penanaman dan pembiakan pada media BAP di lakukan pewarnaan gram untuk diketahui jenis bakteri apa yang terdapat pada media tersebut.

\section{Pembuatan Suspensi Bakteri}

Pembuatan suspensi bakteri dilakukan dengan cara diambil 1 ose bakteri dari koloni BAP yang telah diinkubasi selama 1 x 24 jam di masukkan ke dalam tabung yang berisi $\mathrm{NaCl}$ steril sebanyak 3ml kemudian dihomogenkan. Kemudian amati kekeruhannya dengan menggunakan standar Mc Farland untuk melihat kepadatan bakteri yang akan ditanam di media MHA. 


\section{Uji Sensitifitas Antibiotik}

Uji sensitivitas ini menggunakan metode disc diffusion (Kirby Bauer). Uji sensitivitas menggunakan cakram ampisilin dan sefotaksim. Inkubasi 1 x 24 jam dengan suhu $37^{\circ} \mathrm{C}$, ukur masing-masing zona hambat dari cakram yang telah di tanam di media MHA. Pengukuran diameter zona hambatan dengan menggunakan penggaris atau dial caliper. Pengukuran hasil diameter zona hambat disesuaikan dengan klasifikasi respon hambat pertumbuhan bakteri berdasarkan Clinical Laboratory Standar Institute (CLSI) (9).

Tabel 1 Interpretasi zona ukur bakteri (9)

\begin{tabular}{llccc}
\hline Antibiotik & Potensi Cakram & Resisten & Intermedian & Sensitif \\
\hline Ampisiline & $10 \mu \mathrm{g} / \mathrm{ml}$ & $\leq 13 \mathrm{~mm}$ & $14-16$ & $\geq 17 \mathrm{~mm}$ \\
Sefotaksim & $30 \mu \mathrm{g} / \mathrm{ml}$ & $\leq 22 \mathrm{~mm}$ & $23-25 \mathrm{~mm}$ & $\geq 26 \mathrm{~mm}$ \\
\hline
\end{tabular}

\section{HASIL DAN PEMBAHASAN}

Penetapan tingkat sensitivitas bakteri penyebab penyakit Infeksi Saluran Pernapasan Akut Hasil terhadap bakteri dengan membandingkan hasil pengukuran diameter zona hambat dengan standar CLSI (Tabel 1). Hasil interpretasi diameter zona hambat antibiotik ampisilin hampir seluruhnya resistensi $(86,26 \%)$, sebagian kecil masih sensitif $(13,63)$. Sedangkan pada antibiotik sefotaksim tidak jauh berbeda dengan ampisilin, sebagian besar terjadi resistensi $(63,64 \%)$, intermedien sebanyak 4,55\%, dan yang masih sensitif sebanyak $31,81 \%$ terhadap bakteri yang menginfeksi saluran pernapasan.

Dari data karakteristik pasien yang terlibat dalam penelitian diketahui perbandingan jumlah pasien berdasarkan jenis kelamin tidak jauh beda, yang terbanyak adalah laki-laki $(54,54 \%)$. Sama halnya dengan beberapa data penelitian lainnya yang berkaitan dengan penyakit ISPA menyebutkan perbedaan jumlah pasien ISPA berdasarkan jenis kelamin tidak jauh beda (10). Dari hasil pengelompokan pasien berdasarkan umur diketahui jumlah pasien terbanyak pada kelompok umur 31-50 tahun sebanyak 45\%. Menurut hasil Riset Kesehatan Dasar tahun 2018, kelompok umur yang rentan terkena ISPA ialah pada usia 1 hingga 4 
tahun (11). Pada penelitian ini sengaja tidak mengambil sampel dari pasien anakanak karena pasien anak susah dalam mengeluarkan sputum.

Tabel 2 Karakteristik pasien Infeksi Saluran Pernapasan Akut di Rumah Sakit Bhayangkara Kota Bengkulu yang memenuhi kriteria inklusi

\begin{tabular}{lcc}
\hline Karakteristik Responden & Jumlah (n\%) \\
\hline Jenis Kelamin & 12 & $(54,54 \%)$ \\
$\quad$ Laki-laki & 10 & $(45,45 \%)$ \\
$\quad$ Perempuan & & \\
\hline Umur & 4 & $(18,18 \%)$ \\
$\quad<30$ th & 10 & $(45,45 \%)$ \\
$31-50$ th & 3 & $(13,63 \%)$ \\
$51-64$ th & 5 & $(22,72 \%)$ \\
\hline
\end{tabular}

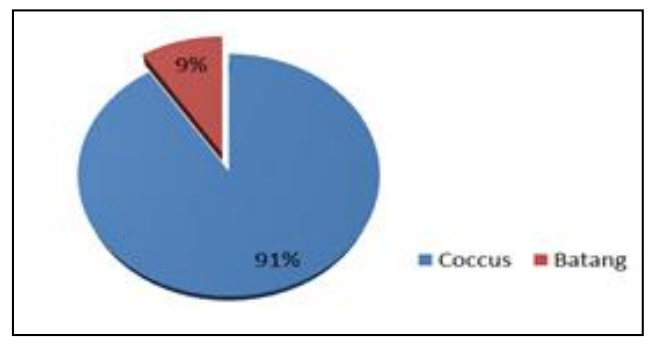

Gambar 1 Morfologi bakteri penyebab Infeksi Saluran Pernapasan Akut

Berdasarkan hasil pewarnaan kultur bakteri dari 22 sampel sputum teridentifikasi bahwa seluruhnya merupakan bakteri gram positif dan pengamatan morfologi tampak sebagian besar bakteri berbentuk coccus (Gambar 1). Secara umum penyebab ISPA adalah berbagai mikroorganisme, namun kebanyakan diakibatkan oleh virus dan bakteri. Bakteri yang paling sering menjadi penyebab ISPA adalah Streptococcus pneumonia, Neisseria gonorrhoeae, Haemophilus influenza, Chlamydia pneumonia, Bordetella pertussis Moraxella catarrhalis, Klebsiella pneumoniae, Staphylococcus aureus, Pseudomonas aeruginosa dan Escherichia coli (12) (13) (14) (15). Bakteri-bakteri penyebab ISPA tersebut kebanyakan berbentuk coccus sesuai dengan hasil identifikasi sampel sputum pasien. Penelitian ini memiliki keterbatasan tidak mengidentifikasi bakteri penyebab ISPA hingga nama spesiesnya. 


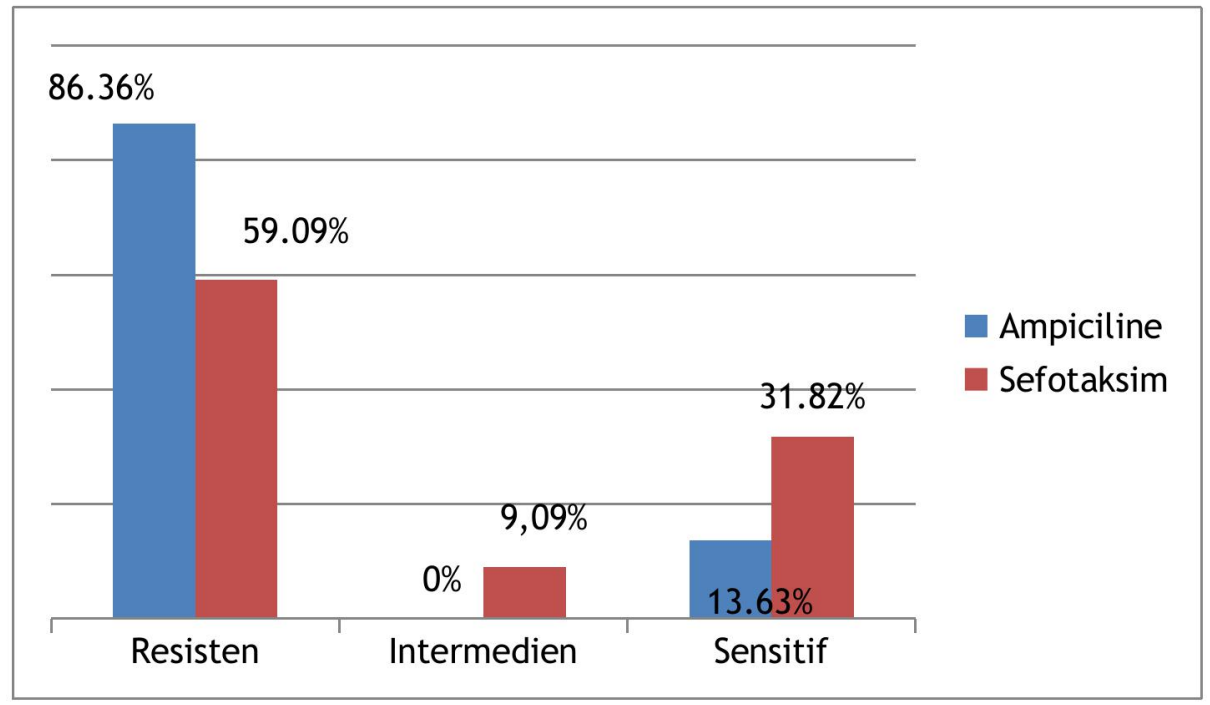

Gambar 2 Persentase Sensitifitas antibiotik terhadap bakteri penyebab Infeksi Saluran Pernapasan Akut

Kultur bakteri yang dibiakkan dari sputum pasien ISPA dilakukan pengujian tingkat resistensi terhadap antibiotik ampisilin dan sefotaksim. Ampisilin merupakan antibiotik spektrum luas yang dapat membunuh bakteri gram-positif maupun negatif seperti Haemophilus influenzae, Escherichia coli, dan Proteus mirabilis. Mekanisme kerja ampisilin adalah dengan menghambat sintesis dinding sel bakteri.

Sefotaksim merupakan antibiotik golongan sefalosporin generasi ketiga yang memiliki spektrum bakteri yang luas. Sefotaksim di gunakan untuk pengobatan meningitis yang disebabkan oleh pneumococci, meningococci, dan Haemophilus influenzae (16). Mekanisme kerja sefotaksim dalam membunuh bakteri adalah dengan menghambat sintesis dinding sel bakteri. Ampisilin dan sefotaksim merupakan antibiotika golongan bakterisid.

Hasil penelitian ini menunjukan ampisilin hampir seluruhnya $(86,26 \%)$ resisten dan sebagian kecil $(13,63 \%)$ sensitif terhadap bakteri yang diisolasi dari sputum pasien. Hasil yang hampir sama didapatkan pada pengujian sefotaksim pada bakteri penyebab ISPA yang telah diisolasi, yaitu terjadi resistensi sebanyak 59,09\% dan jumlah bakteri yang masih sensitif hanya 31,81\%. Tingginya angka resistensi antibiotik juga dilaporkan oleh beberapa hasil penelitian, seperti yang Antimicrobial Resistant in Indonesia (AMRIN-Study) didapatkan bahwa 43\% Escherichia coli resisten terhadap ampisilin(17). Beberapa hasil penelitian juga menyatakan bahwa 
kejadian resistensi dari sefotaksim juga tinggi(18) (19). Resistensi bakteri terhadap ampisilin dan sefotaxime terjadi dikarenakan bakteri gram positif menghasilkan enzim beta-laktamase, perubahan protein binding peniciillin (PBP) dan enzim autosilin bakteri tidak berkerja. Enzim beta-laktamase mengakibatkan hidrolisis cincin betalaktam pada antibiotik, bakteri akan membuka cincin betalaktam dari ampisilin yang mengakibatkan hilangnya sensitivitas antibiotic (20).

\section{SIMPULAN}

Dari penelitian ini dapat disimpulkan bahwa angka kejadian resistensi bakteri terhadap penggunaan ampisilin dan sefotaksim pada pasien ISPA di salah satu rumah sakit di kota Bengkulu cukup tinggi.

\section{UCAPAN TERIMA KASIH}

Terima kasih kami ucapkan kepada Direktur dan Civitas Akademika Poltekkes Kemenkes Bengkulu atas dukungan moril dan materilnya dalam pelaksanaan penelitian ini.

\section{DAFTAR PUSTAKA}

1. Lim SS, Vos T, Flaxman AD, Danaei G, Shibuya K, Adair-Rohani H, et al. A comparative risk assessment of burden of disease and injury attributable to 67 risk factors and risk factor clusters in 21 regions, 1990-2010: a systematic analysis for the Global Burden of Disease Study 2010. Lancet. 2012;380(9859):2224-60.

2. Departemen Kesehatan RI. Pharmaceutical Care Untuk Penyakit Infeksi Saluran Pernapasan [Internet]. Jakarta; 2005. Available from: http://binfar.kemkes.go.id/v2/wp-content/uploads/2014/02/PC_INFEKSI.pdf

3. LADIPA VB. Evaluasi Penggunaan Antibiotik Pada Pasien Anak Penyakit Infeksi Saluran Pernafasan Atas Akut Di Puskesmas Kecamatan Arjosari Kabupaten Pacitan Tahun 2016. Universitas Muhammadiyah Surakarta; 2018.

4. Ullah A, Kamal Z, Ullah G, Hussain H. To determine the rational use of antibiotics; A case study conducted at medical unit of Hayatabad Medical Complex, Peshawar. Int J Res Appl Nat Soc Sci. 2013;1(2):66. 
5. Blumenthal D, Brunton L1, Buxton Ilo, Parker K1. Goodman \& Gilman's manual of pharmacology and therapeutics. 2008;

6. Barbara GW, Joseph TD, Terry LS, Dipiro C V. Pharmacotherapy Handbook. New York: McGraw Hill Professional; 2015.

7. White AR. Augmentin(R) (amoxicillin/clavulanate) in the treatment of community-acquired respiratory tract infection: a review of the continuing development of an innovative antimicrobial agent. J Antimicrob Chemother. 2004;53(90001):3i - 20 .

8. Richards DM, Heel RC, Brogden RN, Speight TM, Avery GS. Cefotaxime: A Review of its Antibacterial Activity, Pharmacological Properties and Therapeutic Use. Drugs. 1984;27(6):469-527.

9. CLSI. Clinical and Laboratory Standards Institute) Performance standards for antimicrobial susceptibility testing; Ed. by Wayne, P.A.24th informational supplement. CLSI M100-S24,35(3):168-170. Vol. 3, international Journal of Scientific \& Technology Research. 2015. 375-384 p.

10. Tobat SR, Mukhtar MH, Pakpahan IHD. Rasionalitas Penggunaan Antibiotik Pada Penyakit ISPA di Puskesmas Kuamang Kuning I Kabupaten Bungo. Scientia. 2015;5(2):79-83.

11. Kementerian Kesehatan RI. Riset Kesehatan Dasar 2018. 2018.

12. Poole MD, Portugal LG. Treatment of rhinosinusitis in the outpatient setting. Am J Med. 2005;118(7 SUPPL.):45-50.

13. Fendrick AM, Monto AS, Nightengale B, Sarnes M. The economic burden of non-influenza-related viral respiratory tract infection in the United States. Arch Intern Med. 2003;163(4):487-94.

14. Biçer S, Küçük Ö, Giray T, Çöl D, Çiler Erdağ G, Gürol Y, et al. Evaluation of Clinical and Laboratory Findings of Pediatric Patients with AdenovirusAssociated Respiratory Tract Infections. Mikrobiyol Bul. 2013;47(2):295-304.

15. Manikandan C, Amsath A, Nadu T. Antibiotic Susceptibility of Bacterial Strains Isolated from Patients with Respiratory Tract Infections. Int J Pure Appl Zool. 2013;1(1):0. 
16. Katzung BG, Masters SB, Trevor AJ. Basic and Clinical Pharmacology. 12th ed. United States: The McGraw-Hill Companies, Inc.; 2012. 1-1245 p.

17. Kementerian Kesehatan R I. Pedoman Umum Penggunaan Antibiotik. 2013. $1-5 \mathrm{p}$.

18. Nurmala. Pola Bakteri, Resistensi Dan Sensitivitasnya Terhadap Antibiotik Berdasarkan Hasil Kultur Pada Spesimen Pus Di Rumah Sakit Umum Dokter Soedarso Pontianak Tahun 2015. Universitas Tanjungpura Pontianak; 2015.

19. Pradani SA. Pola Kuman Dan Resistensi Bakteri Terhadap Antibiotik Pada Penderita Infeksi Saluran Kemih (Isk) Di Instalasi Rawat Inap Rumah Sakit Pku Muhammadiyah Surakarta Periode Februari-Maret Tahun 2016. Universitas Muhammadiyah Surakarta; 2016.

20. Gunawan SG, Setiabudy R, Nafrialdi E. Farmakologi dan Terapi. 5th ed. Departemen farmakologi dan terapeutik FKUI. Jakarta; 2007. 